\title{
Modification of $\mathrm{Cu} / \mathrm{Cr}$ Layered Double Hydroxide by Keggin Type Polyoxometalate as Adsorbent of Malachite Green from Aqueous Solution
}

\author{
Neza Rahayu Palapa', Tarmizi Taher ${ }^{2}$, Alfan Wijaya ${ }^{3}$, Aldes Lesbani ${ }^{1,3 *}$ \\ ${ }^{1}$ Graduate School of Faculty of Mathematics and Natural Sciences, Sriwijaya University, Palembang, South Sumatra, Indonesia \\ ${ }^{2}$ Department of Environmental Engineering, Institut Teknologi Sumatera, Lampung Selatan, Indonesia \\ ${ }^{3}$ Research Center of Inorganic Materials and Complexes, Faculty of Mathematics and Natural Sciences, Sriwijaya University, Indralaya, Indonesia \\ *Corresponding author: aldeslesbani@pps.unsri.ac.id
}

\begin{abstract}
Modification of $\mathrm{Cu} / \mathrm{Cr}$ layered double hydroxides ( $\mathrm{LDHs}$ ) has been conducted by intercalation using Keggin type polyoxometalate $\left[\alpha-\mathrm{SiW}_{12} \mathrm{O}_{40}\right]^{4-}$ to form CuCr- $\left[\alpha-\mathrm{SiW}_{12} \mathrm{O}_{40}\right]$. The materials were analyzed by XRD, FTIR, and surface area analyses. Furthermore, materials were used as selectivity adsorbents of cationic dyes such as malachite green, rhodamine-B and methylene blue. The malachite green is more selective than others from an aqueous solution. The adsorption of malachite green showed that the adsorption capacity of $\mathrm{CuCr}-\left[\alpha-\mathrm{SiW}_{12} \mathrm{O}_{40}\right]$ was higher than pristine LDHs. The adsorption process was followed pseudo second order kinetic model and Langmuir isotherm adsorption. The $\mathrm{Q}_{\max }$ value of $\mathrm{CuCr}-\left[\alpha-\mathrm{SiW}_{12} \mathrm{O}_{40}\right]$ reached $55.322 \mathrm{mg} / \mathrm{g}$ at $323 \mathrm{~K}$ after $100 \mathrm{~min}-$ utes adsorption time. Thermodynamic parameters such as $\Delta \mathrm{G}, \Delta \mathrm{H}$ and $\Delta \mathrm{S}$ confirm that the adsorption process was endothermic, spontaneous, and more favorable at high temperatures. The intercalated material was higher structural stability toward reusability adsorbent than pristine LDHs.
\end{abstract}

Keywords

Malachite Green, Polyoxometalate, Intercalation, Layered Double Hydroxides, Adsorption

Received: 7 April 2021, Accepted: 20 July 2021

https://doi.org/10.26554/sti.2021.6.3.209-217

\section{INTRODUCTION}

The existence of chemical substances in the environment is a vital topic to discuss until this decade due to toxic properties and caused pollution in the land and aquatic systems. These chemicals including heavy metals, organic pollutants, and also dyes. Dyes substances were produced from industrial activities including textile, plastic, printing, leather, and so on (Abdelkader et al., 2011). These dyes are usually released to the environment directly without gradually further treatment thus can impact humans, flora, and fauna (Dahri et al., 2014). The removal of dyes from wastewater is an important way to minimize the serious effect. Various physicochemical and biological methods have been applied to remove dyes from wastewater such as adsorption, coagulation, filtration, precipitation, light decomposition, and also using bacterial process (Dai et al., 2018; Gholami et al., 2020; Srinivasan and Sadasivam, 2018; Xu et al., 2018b). Among these methods, adsorption is a suitable method for the removal of dyes from wastewater due to fast process, simple way, easy procedure, and also no contamination effect before and after the process (Nazir et al., 2020; Jarrah et al., 2020; Naseeruteen et al., 2018). The effec- tiveness of the adsorption process is depending on the ability of the adsorbent. Various kinds of adsorbents have been used for removing dyes from wastewater such as zeolites (Oliveira et al., 2019), activated carbon (Mall et al., 2005), natural layer structure materials such as bentonite and kaolinite (Bulut et al., 2008), and also synthetic materials such as layered double hydroxides (Das et al., 2018; Lesbani et al., 2020c; Parida and Mohapatra, 2012).

Layered double hydroxide (LDHs) is a class of synthetic layer materials with positively charged and consists of interlayer anions (Lesbani et al., 2020a). Interlayer anions can be exchanged with various anions to increase interlayer distance or gallery of LDHs. The general formula of LDHs is $\left.\left[\mathrm{M}^{2+}{ }_{1-x} \mathrm{M}^{3+}{ }_{x}(\mathrm{OH})_{2}\right]^{x+}\left(\mathrm{A}^{n-}\right)_{x / n}\right] \cdot \mathrm{nH}_{2} \mathrm{O}$, where $\mathrm{M}$ is divalent and trivalent metal ions and $\mathrm{A} n-$ is interlayer anions with valence $n$ (Palapa et al., 2020b). The interlayer of LDHs contains anions such as nitrate, chloride, sulfate, and other ions due to synthetic conditions (Doungmo et al., 2016; Lesbani et al., 2020b; Parida and Mohapatra, 2012). The unique properties of interlayer LDHs is the ion exchange properties. Interlayer anions can be exchanged with other anions to obtain a high interlayer distance of LDHs (Ma et al., 2013; Oktriyanti et al., 


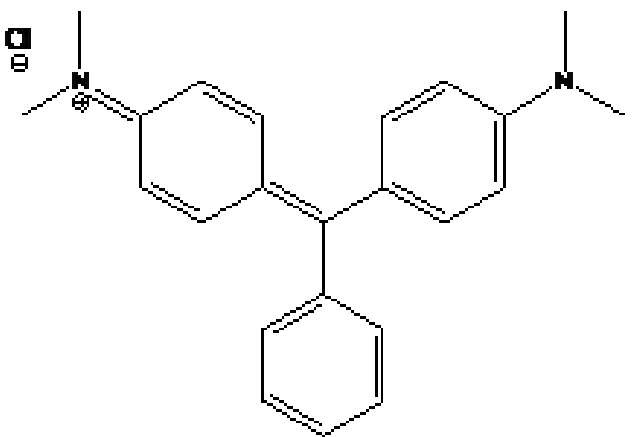

Figure 1. Chemical structure of Malachite Green

2020; Zhu et al., 2017). These novel properties are useful for various applications of LDHs such as adsorbents (Shan et al., 2015), catalysts (Sun et al., 2019), biomedical materials (Liao and Chen, 2016), and other industrial applications (Zubair et al., 2017).

Adsorption of dyes using LDHs has been tested for various dyes such as methylene blue (Lesbani et al., 2020a), indigo carmine (Starukh and Levytska, 2019), methyl orange (Elmoubarki et al., 2017), and malachite green (Lesbani et al., 2020c). That dyes are classified as cationic and anionic dyes depending on the structures of dyes. One of the toxic dyes is malachite green. This dye is classified as a cationic dye with the chemical structure shown in Figure 1.

LDHs are almost treated with physical or chemical techniques before being applied as an adsorbent in the adsorption process (Silaen, 2020). This step aims to increase the surface area and interlayer distance of LDHs for active sites of adsorption. On the other hand, intercalation using a large anion is effective to increase the interlayer distance of LDHs and surface area properties (Palapa et al., 2020a). Large anions such as polyoxometalate ions are frequently used as an anion for the intercalation process onto LDHs (Legagneux et al., 2009). Then materials after intercalation were applied as adsorbents of dyes (Lesbani et al., 2020b). Polyoxometalates are metal-oxygen cluster compounds with various structures such as Keggin, Dawson, Anderson, and also Lacunary form (Carriazo et al., 2007; Yang et al., 2012; Yun and Pinnavaia, 1996). Among these structures, Keggin is well known used not only as a catalyst (Lesbani et al., 2015) and building blocks (Long et al., 2010) but also for intercalation anion of LDHs (Bi et al., 2011). According to Nijs et al. (1999) MgAl LDH was intercalated using $\left[\mathrm{H}_{2} \mathrm{~W}_{12} \mathrm{O}_{40}\right]^{6-}$ to form pillared compounds with various mass ratios of polyoxometalate. The others type of polyoxometalate $\mathrm{K}_{3}\left[\alpha-\mathrm{PW}_{12} \mathrm{O}_{40}\right]$ and $\mathrm{K}_{4}\left[\alpha-\mathrm{SiW}_{12} \mathrm{O}_{40}\right]$ have been carried out as intercalants on $\mathrm{ZnAl}$ and $\mathrm{CaAl} \mathrm{LDH}$ as reported by Lesbani et al. (2018); Taher et al. (2019). According to previous research, the $\mathrm{LDH}$ intercalated using polyoxometalate has been reported to enhance adsorptive capacity. Xu et al. (2018a) reported that ZnAlFe-polyoxometalate was applied as an adsorbent to remove methylene blue in an aqueous solution and obtained an adsorptive capacity is $67.47 \mathrm{mg} / \mathrm{g}$. Bi et al. (2011), also reported that $\mathrm{ZnAl}-\left[\mathrm{PW}_{10} \mathrm{Mo}_{2} \mathrm{O}_{40}\right]^{5-}$ was conducted to remove cationic dyes. The adsorption capacity of $\mathrm{ZnAl}-\left[\mathrm{PW}_{10} \mathrm{Mo}_{2} \mathrm{O}_{40}\right]^{5-}$ slightly enhanced compared $\mathrm{ZnAl}$ pristine (from $12 \mathrm{mg} / \mathrm{g}$ to $30 \mathrm{mg} / \mathrm{g}$ ).

In this research, polyoxometalate Keggin ion $\left[\alpha-\mathrm{SiW}_{12}\right.$ $\left.\mathrm{O}_{40}\right]^{4-}$ was used as an intercalant of copper-chromium $(\mathrm{CuCr})$ $\mathrm{LDH}$ s to form $\mathrm{CuCr}-\left[\alpha-\mathrm{SiW}_{12} \mathrm{O}_{40}\right]$ LDHs. Materials were characterized using X-Ray diffraction, FTIR spectroscopy, and nitrogen adsorption-desorption isotherm analysis. Furthermore, intercalated and pristine LDHs were applied as adsorbents of malachite green from an aqueous solution. Before the adsorption process was conducted, the selectivity adsorption has been examined using a mixing solution of malachite green (MG), rhodamine-B (Rh-B) and methylene blue (MB). Adsorption was studied by a batch system using a small reactor equipped with stirring and temperature control. Based on the above explanation, the objective of this study is to determine the kinetic parameter, isotherm adsorption and thermodynamic studies of $\mathrm{MG}$ on intercalated and pristine $\mathrm{CuCr}$ LDHs. Structural stability of $\mathrm{CuCr}-\left[\alpha-\mathrm{SiW}_{12} \mathrm{O}_{40}\right]$ toward reusability adsorbent was also investigated systematically.

\section{EXPERIMENTAL SECTION}

\subsection{Chemical and Instrumentation}

The chemicals were purchased from Merck ${ }^{\circledR}$ such as $\mathrm{Cu}\left(\mathrm{NO}_{3}\right)_{2}$ $.6 \mathrm{H}_{2} \mathrm{O}, \mathrm{Cr}\left(\mathrm{NO}_{3}\right)_{3} .9 \mathrm{H}_{2} \mathrm{O}, \mathrm{NaOH}, \mathrm{Na}_{2} \mathrm{CO}_{3}, \mathrm{Na}_{2} \mathrm{WO}_{4}, \mathrm{KCl}$, $\mathrm{Na}_{2} \mathrm{SiO}_{3}$ and $\mathrm{HCl}$. Water was supplied from Research Center of Inorganic Materials and Complexes, FMIPA Universitas Sriwijaya through filtration using Purite ${ }^{\circledR}$ water ion exchange system under several times cycling process. The materials were characterized by XRD Rigaku Miniflex-6000. Sample was grounded with mortar and analyzed using XRD at diffraction $5-60^{\circ}$ with scan speed $1 \%$ min. Analysis of functional group was performed using FTIR Shimadzu Prestige-21. Sample was mixed with $\mathrm{KBr}$ and was vacuumed to form $\mathrm{KBr}$ pellet. Sample was analyzed in the wavenumber $400-4000 \mathrm{~cm}^{-1}$. Analysis of nitrogen adsorption-desorption was conducted using Micrometric ASAP Quantachrome apparatus. Sample was degassed several times prior analysis using liquid $\mathrm{N}_{2}$ to remove guests. Analysis of malachite green was conducted using UV-Visible Spectrophotometer Bio-Base BK-UV 1800 PC. Malachite green was analyzed at $617 \mathrm{~nm}$.

\subsection{Preparation of $\mathrm{CuCr} \mathrm{LDHs}$}

Preparation of $\mathrm{CuCr} \mathrm{LDH}$ s was carried out by precipitation method as follows. As much as $7.5 \mathrm{M}$ solution of $\mathrm{Cu}\left(\mathrm{NO}_{3}\right)_{2}$. $6 \mathrm{H}_{2} \mathrm{O} 0.05 \mathrm{~L}$ was added into $2.5 \mathrm{M}$ solution of $\mathrm{Cr}\left(\mathrm{NO}_{3}\right)_{3}$. $9 \mathrm{H}_{2} \mathrm{O} 0.05 \mathrm{~L}$ with vigorous stirring. The mixing solution was stirred for an hour then $4 \mathrm{M}$ solution of $\mathrm{NaOH} 0.025 \mathrm{~L}$ was added and the solution was adjusted to $\mathrm{pH} 10$ by the addition of $\mathrm{NaOH} 4 \mathrm{M}$. The mixing solution was kept for 16 hours to form a gel. The gel was filtered and washed with water several times and dried at $100^{\circ} \mathrm{C}$ for 24 hours. 


\subsection{Preparation of $\mathrm{CuCr}-\left[\alpha-\mathrm{SiW}_{12} \mathrm{O}_{40}\right] \mathrm{LDHs}$}

The intercalation of $\mathrm{CuCr} \mathrm{LDH}$ s with $\left[\alpha-\mathrm{SiW}_{12} \mathrm{O}_{40}\right]^{4-}$ was conducted by ion-exchange technique. Ion $\left[\alpha-\mathrm{SiW}_{12} \mathrm{O}_{40}\right]^{4-}$ was prepared by previously reported literature (Lesbani et al., 2015). As much as $2 \mathrm{~g}$ of $\mathrm{CuCr} \mathrm{LDH}$ was dissolved into 0.05 $\mathrm{L}$ of water. Polyoxometalate $\mathrm{K}_{4}\left[\alpha-\mathrm{SiW}_{12} \mathrm{O}_{40}\right](15 \mathrm{~g})$ was dissolved with $0.05 \mathrm{~L}$ water. The solution of $\mathrm{CuCr} \mathrm{LDH}$ s was mixed with polyoxometalate solution with mild stirring under nitrogen flow for 24 hours to form a suspension. The suspension was filtered and washed several times using water and dried at room temperature.

\subsection{Adsorption Study and Reusability Adsorbent}

Before the adsorption process was conducted, the selectivity adsorption has been tested. This study aimed to show the materials have good selectivity for specific cationic dyes. The mixture of cationic dyes such as MG, Rh-B and MB was prepared with $10 \mathrm{~mL}$ and the initial concentration of each dye is $15 \mathrm{mg} / \mathrm{L}$. The adsorption of MG was performed by batch system equipped with a stirring bar and temperature system control. The adsorption process was studied by variation of adsorption times, temperatures, and MG concentrations. The mass of adsorbent was carried out using $25 \mathrm{mg}$. The volume of adsorbate was $25 \mathrm{~mL}$. Variation of adsorption time was studied in the range of 5-210 minutes. Variation of initial concentration of MG was studied at $10,25,50$ and $75 \mathrm{mg} / \mathrm{L}$. Variation of adsorption temperature was studied at $303,313,318$, and 323 $\mathrm{K}$. The adsorption parameter was obtained through calculation by kinetic model, isotherm adsorption and thermodynamic parameters. Concentration of MG after adsorption was analyzed by UV-Visible Spectrophotometer at $617 \mathrm{~nm}$.

The kinetic model was calculated using pseudo first order (P-FO) and pseudo second (P-SO) kinetic models by equation below (Doğan and Alkan, 2003):

$$
\begin{aligned}
& \log \left(\mathrm{q}_{e}-\mathrm{q}_{t}\right)=\log \mathrm{q}_{e}-\left(\frac{k_{1}}{2.303}\right) \mathrm{t} \\
& \frac{\mathrm{t}}{\mathrm{q}_{t}}=\frac{1}{\mathrm{k}_{2} \mathrm{q}_{e}{ }^{2}}+\frac{1}{\mathrm{q}_{e}} \mathrm{t}
\end{aligned}
$$

Where, $\mathrm{q}_{e}$ is adsorption capacity at equilibrium $(\mathrm{mg} / \mathrm{g}) ; \mathrm{q}_{t}$ is adsorption capacity at $\mathrm{t}(\mathrm{mg} / \mathrm{g})$; $\mathrm{t}$ is adsorption time (minute); $\mathrm{k}_{1}$ is adsorption kinetic rate at $\mathrm{P}-\mathrm{FO}\left(/\right.$ minute) and $\mathrm{k}_{2}$ is adsorption kinetic rate at $\mathrm{P}-\mathrm{SO}$ (g/mg.min).

Isotherm adsorption study was conducted by Langmuir and Freundlich equation as written as (Obike et al., 2018):

$$
\begin{aligned}
& \frac{1}{\mathrm{q}_{e}}=\frac{1}{\mathrm{q}_{\max }}+\frac{1}{\mathrm{q}_{\text {max }} \mathrm{b}} \cdot \frac{1}{\mathrm{C}_{e}} \\
& \ln \mathrm{q}_{e}=\ln \mathrm{K}_{f}+\left(\frac{1}{n}\right) \ln \mathrm{C}_{e}
\end{aligned}
$$

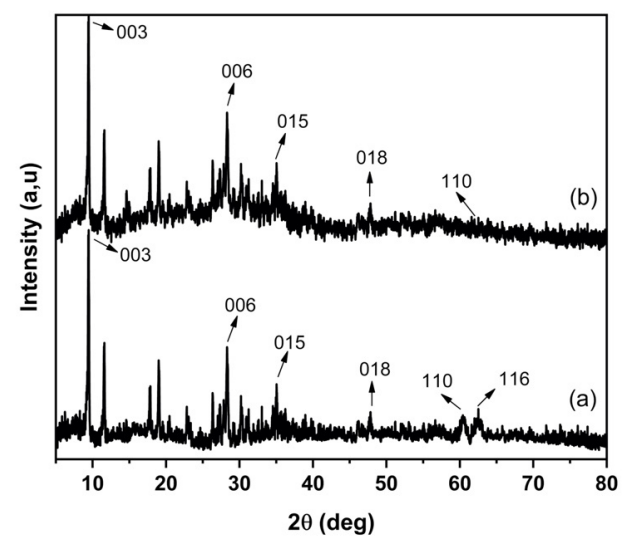

Figure 2. XRD powder Patterns of $\mathrm{CuCr}$ (a) and $\mathrm{CuCr}\left[\alpha-\mathrm{SiW}_{12} \mathrm{O}_{40}\right] \mathrm{LDHs}$

Where, $\mathrm{q}_{\max }$ is the maximum adsorption capacity conducted in the monolayer $(\mathrm{mg} / \mathrm{g})$; $\mathrm{b}$ is the Langmuir adsorption equilibrium constant $(1 / \mathrm{mg})$; $\mathrm{C}_{e}$ is the equilibrium concentration $(\mathrm{mg} / \mathrm{L})$; and $\mathrm{K}_{f}$ is Freundlich constant.

The reusability of adsorbent was conducted to investigate the structural stability of adsorbent toward adsorption. Desorption of malachite green was performed using ultrasonic system and adsorbent was reuse for the next adsorption process. The dried adsorbent was reused for three cycles with a similar procedure.

\section{RESULTS AND DISCUSSION}

Materials of $\mathrm{CuCr}$ and $\mathrm{CuCr}-\left[\alpha-\mathrm{SiW}_{12} \mathrm{O}_{40}\right]$ were characterized using XRD diffraction as shown in Figure 2. The characteristic diffraction of $\mathrm{CuCr} \mathrm{LDHs}$ appeared at $9.89^{\circ}(003)$, $27.32^{\circ}(006), 36.10^{\circ}(015), 48.98^{\circ}(018), 60.60^{\circ}(110)$, and $62.55^{\circ}$ (116) (Palapa et al., 2020b). The diffraction peak at $9.89^{\circ}$ with reflection 003 denote the interlayer space of $\mathrm{LDHs}$ Material $\mathrm{CuCr}-\left[\alpha-\mathrm{SiW}_{12} \mathrm{O}_{40}\right]$ showed similar diffraction as pristine $\mathrm{LDH}$, but the interlayer of $\mathrm{CuCr}-\left[\alpha-\mathrm{SiW}_{12} \mathrm{O}_{40}\right]$ was increased from $7.55 \AA$ to $10.27 \AA$. However, the intercalation of $\left[\alpha-\mathrm{SiW}_{12} \mathrm{O}_{40}\right]$ onto $\mathrm{CuCr} \mathrm{LDHs}$ can increase basal spacing up to $2.72 \AA$.

The FTIR spectra of $\mathrm{CuCr}$ and $\mathrm{CuCr}-\left[\alpha-\mathrm{SiW}_{12} \mathrm{O}_{40}\right]$ were shown in Figure 3. FTIR spectrum of $\mathrm{CuCr}$ LDHs showed the intense vibration at $1381 \mathrm{~cm}^{-1}$ denotes as nitrate bending. The broad vibration was identified at wavenumber $3448 \mathrm{~cm}^{-1}$ due to $\mathrm{OH}$ stretching from water molecule. The water-associated vibration also appeared at $1627 \mathrm{~cm}^{-1}$, which was assigned as bending $\mathrm{OH}$ vibration (Daniel and Thomas, 2020). The intercalation of $\mathrm{CuCr} \mathrm{LDHs}$ with $\left[\alpha-\mathrm{SiW}_{12} \mathrm{O}_{40}\right]^{4-}$ ion will replace the nitrate as anion on interlayer space. The FTIR spectrum after intercalation showed the vibration around 1107 $\mathrm{cm}^{-1}$, which was assigned as the presence of another anion $(\mathrm{C}$ O) from carbonate. The unique vibration of $\left[\alpha-\mathrm{SiW}_{12} \mathrm{O}_{40}\right]$ from $\mathrm{CuCr}-\left[\alpha-\mathrm{SiW}_{12} \mathrm{O}_{40}\right]$ shows at wavenumber below 1000 $\mathrm{cm}^{-1}(\mathrm{~W}=\mathrm{O}$ and $\mathrm{Si}-\mathrm{O})$. 


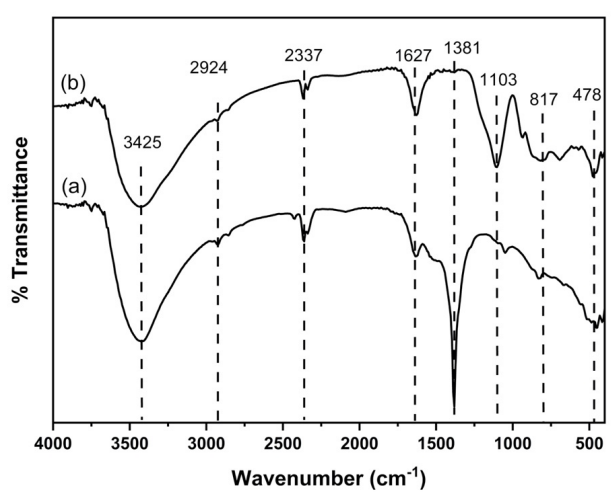

Figure 3. FTIR Spectrum of $\mathrm{CuCr}$ and $\mathrm{CuCr}-\left[\alpha-\mathrm{SiW}_{12} \mathrm{O}_{40}\right]$ $\mathrm{LDHs}$

Analysis of adsorption-desorption nitrogen on $\mathrm{CuCr}$ and $\mathrm{CuCr}-\left[\alpha-\mathrm{SiW}_{12} \mathrm{O}_{40}\right]$ is shown in Figure 4 . The profile of adsorption-desorption nitrogen is categorized as type IV with H3 hysteresis loop for both LDHs. The isotherm pathway indicated the mesopore materials, which were associated with capillary condensation (Harizi et al., 2019). The BET calculation was obtained from data in Figure 4 as shown in Table 1.

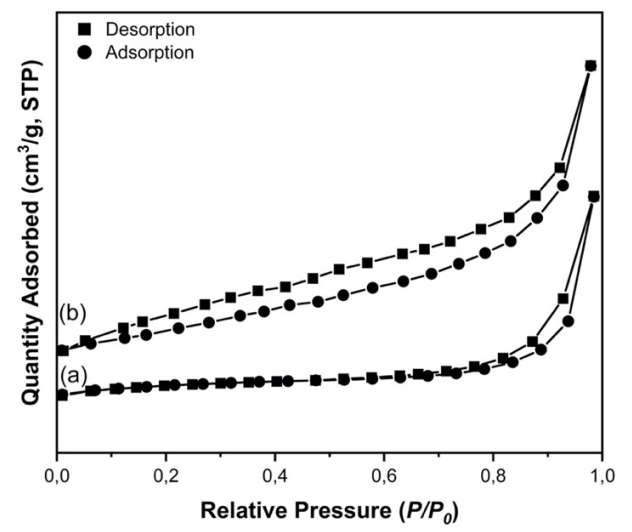

Figure 4. Nitrogen Adsorption-Desorption of $\mathrm{CuCr}$ and $\mathrm{CuCr}-\left[\alpha-\mathrm{SiW}_{12} \mathrm{O}_{40}\right]$ LDHs

The data in Table 1. showed the BET analysis of $\mathrm{CuCr}$ and $\mathrm{CuCr}-\left[\alpha-\mathrm{SiW}_{12} \mathrm{O}_{40}\right] \mathrm{LDH}$. The increase of the surface area of LDHs after intercalation by $\left[\alpha-\mathrm{SiW}_{12} \mathrm{O}_{40}\right]$ was found with the decreases in the pore size. Thus, the decreases in pore size indicated the swelling and the covering of interlayer space by macroanion $\left[\alpha-\mathrm{SiW}_{12} \mathrm{O}_{40}\right]^{4-}$. These phenomena are related to the opening of interlayer space, which was confirmed by XRD analysis (Ouassif et al., 2020). The surface area of $\mathrm{CuCr}-\left[\alpha-\mathrm{SiW}_{12} \mathrm{O}_{40}\right]$ was increased up to fivefold than $\mathrm{CuCr}$ LDHs. LDHs intercalated by polyoxometalate are potential material as an adsorbent to remove pollutants from wastewater. Furthermore, to determine the adsorption ability of $\mathrm{CuCr}-[\alpha-$ $\mathrm{SiW}_{12} \mathrm{O}_{40}$ ], the adsorption selectivity of cationic dyes (MG,
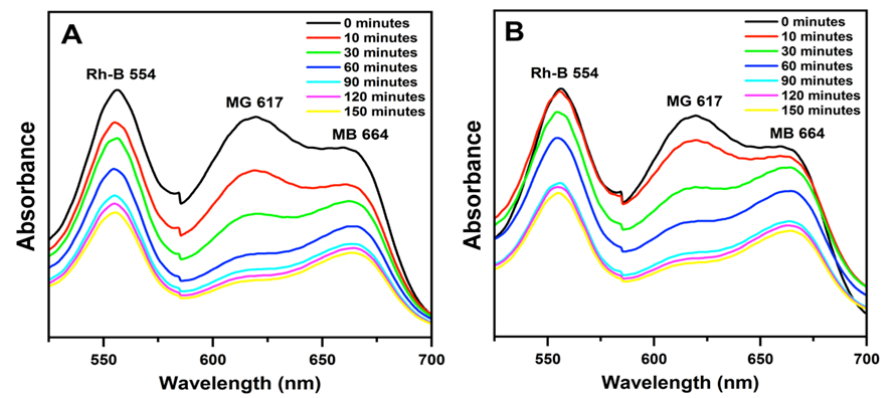

Figure 5. Wavelength Scan of Selectivity Adsorption by $\mathrm{CuCr}-\left[\alpha-\mathrm{SiW}_{12} \mathrm{O}_{40}\right]$ (a) and $\mathrm{CuCr}$ (b) LDHs onto Mixing $\mathrm{MG}, \mathrm{Rh}-\mathrm{B}$ and MB
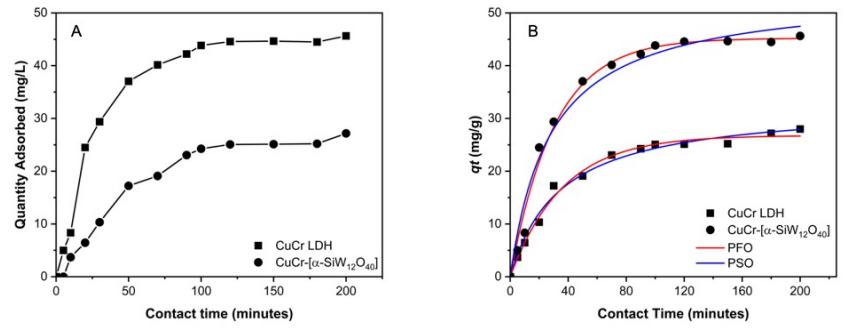

Figure 6. Effect of Adsorption Time (A) and Kinetic Model (B)

Rh-B and MB) has been studied as shown in Figure 5. Figure 5(A) showed that $\mathrm{CuCr}-\left[\alpha-\mathrm{SiW}_{12} \mathrm{O}_{40}\right]$ adsorbed MG higher than other cationic dyes. The decrease in absorbance value indicates a decrease in initial concentration. However, the decrease dramatically of initial concentration of MG indicated that the small structure of MG than Rh-B and MB (Mohadi et al., 2021). Figure 5(B) also showed a similar finding that MG more selectivity than others. The final concentration of MG after 150 min of $\mathrm{CuCr}$ and $\mathrm{CuCr}-\left[\alpha-\mathrm{SiW}_{12} \mathrm{O}_{40}\right]$ are 8.1 and $5.4 \mathrm{mg} / \mathrm{L}$, respectively. Thus, the $\mathrm{CuCr}-\left[\alpha-\mathrm{SiW}_{12} \mathrm{O}_{40}\right]$ was used as an adsorbent to remove MG from the aqueous solution. The adsorption process was carried out by the effect of adsorption time, the effect of MG concentration and adsorption temperature. The effect of adsorption time for MG removal using $\mathrm{CuCr}$ and $\mathrm{CuCr}-\left[\alpha-\mathrm{SiW}_{12} \mathrm{O}_{40}\right]$ was shown in Figure 6.

Figure 6(A) showed MG was higher adsorbed using $\mathrm{CuCr}-$ $\left[\alpha-\mathrm{SiW}_{12} \mathrm{O}_{40}\right]$ than pristine LDHs. This finding assumed that the higher surface area of $\mathrm{CuCr}-\left[\alpha-\mathrm{SiW}_{12} \mathrm{O}_{40}\right]$ after intercalation. The equilibrium amount of $\mathrm{MG}$ on $\mathrm{CuCr}-\left[\alpha-\mathrm{SiW}_{12} \mathrm{O}_{40}\right]$ was reached after 100 minutes with MG removal up to $90 \%$ from the initial concentration $50 \mathrm{mg} / \mathrm{L}$. The results showed that MG uptake on $\mathrm{CuCr}-\left[\alpha-\mathrm{SiW}_{12} \mathrm{O}_{40}\right]$ were higher twice than $\mathrm{CuCr}$ LDHs. Thus, the adsorption kinetic was determined by pseudo kinetic model. Figure 6(B) showed the fitted of two kinetic models. The calculated parameters were listed in Table 2. Based on Figure 6(B) and Table 2, kinetic adsorption of $\mathrm{MG}$ on $\mathrm{CuCr}$ and $\mathrm{CuCr}-\left[\alpha-\mathrm{SiW}_{12} \mathrm{O}_{40}\right]$ were followed PS-O model with coefficient correlation $>0.963$. 
Table 1. BET Surface Area Analysis of $\mathrm{CuCr}$ and $\mathrm{CuCr}-\left[\alpha-\mathrm{SiW}_{12} \mathrm{O}_{40}\right] \mathrm{LDHs}$

\begin{tabular}{ccc}
\hline Materials & Surface Area $\left(\mathrm{m}^{2} / \mathrm{g}\right)$ & Pore Size $(\mathrm{nm})$ \\
\hline $\mathrm{CuCr} \mathrm{LDH}$ & 4.58 & 14.39 \\
$\mathrm{CuCr}\left[\alpha-\mathrm{SiW}_{12} \mathrm{O}_{40}\right]$ & 26.58 & 2.023 \\
\hline
\end{tabular}

Table 2. Kinetic Parameter of Adsorption on $\mathrm{CuCr}$ and $\mathrm{CuCr}\left[\alpha-\mathrm{SiW}_{12} \mathrm{O}_{40}\right]$

\begin{tabular}{cccccccc}
\hline \multirow{2}{*}{ Adsorbent } & $\mathrm{Qe}_{\text {exp }}$ & \multicolumn{3}{c}{$\mathrm{P}-\mathrm{FO}$} & \multicolumn{3}{c}{ P-SO } \\
& $(\mathrm{mg} / \mathrm{g})$ & $\mathrm{qe}_{\text {Calc }}(\mathrm{mg} / \mathrm{g})$ & $\mathrm{R}^{2}$ & $\mathrm{k}_{1}$ & $\mathrm{qe}_{\text {Calc }}(\mathrm{mg} / \mathrm{g})$ & $\mathrm{R}^{2}$ & $\mathrm{k}_{2}$ \\
\hline $\mathrm{CuCr}$ & 27.985 & 23.051 & 0.948 & 0.017 & 31.24 & 0.977 & 0.001 \\
$\mathrm{CuCr}\left[\alpha-\mathrm{SiW}_{12} \mathrm{O}_{40}\right]$ & 18.354 & 45.651 & 0.924 & 0.023 & 52.619 & 0.963 & 0.0007 \\
\hline
\end{tabular}
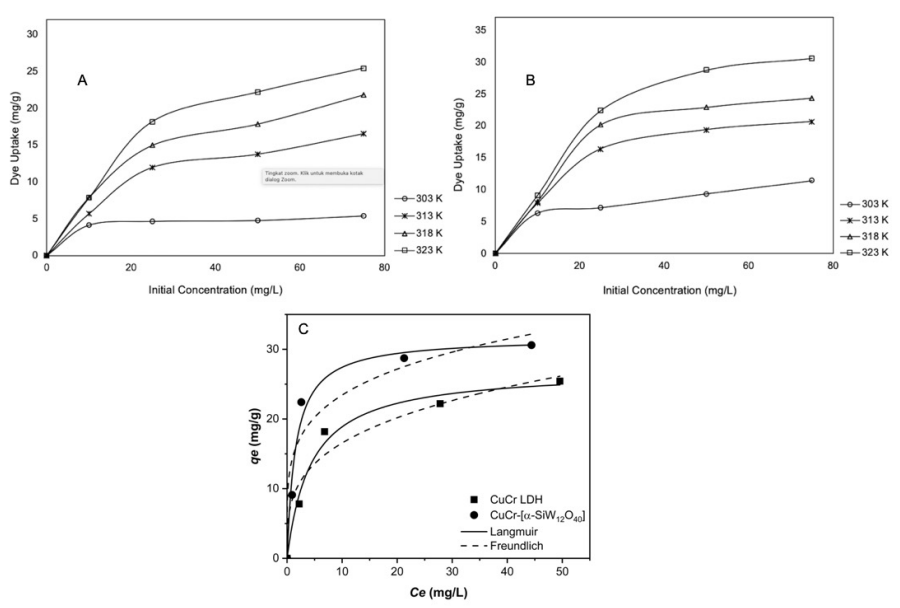

Figure 7. Effect of Initial Concentration of MG and Adsorption

The effect of initial concentration and adsorption temperature of MG were presented in Figure 7. The amount of MG adsorbed on $\mathrm{CuCr}-\left[\alpha-\mathrm{SiW}_{12} \mathrm{O}_{40}\right]$ was increased by increasing adsorption temperature, which was conducted on a batch adsorption system. The adsorption patterns for both materials have equilibrium after $20 \mathrm{mg} / \mathrm{L}$ and higher $\mathrm{MG}$ was adsorbed at $323 \mathrm{~K}$. Furthermore, the data of initial concentration and adsorption temperature for both materials were calculated using Langmuir and Freundlich isotherm model to obtain isotherm adsorption.

The data in Table 3 showed that adsorption of MG by $\mathrm{CuCr}$ and $\mathrm{CuCr}-\left[\alpha-\mathrm{SiW}_{12} \mathrm{O}_{40}\right]$ follow Langmuir isotherm adsorption model rather than Freundlich model. The coefficient correlation for Langmuir isotherm is almost close to one than Freundlich isotherm. The qmax for $\mathrm{CuCr}-\left[\alpha-\mathrm{SiW}_{12} \mathrm{O}_{40}\right]$ is higher than pristine LDHs. As expected of increasing surface area properties thus this higher of $\mathrm{q}_{\max }$ value is matched results. Thus, Table 4 . Showed MG adsorption using several adsorbents.

Table 4 showed the comparison of malachite green adsorption using several adsorbents. Based on results, the adsorption

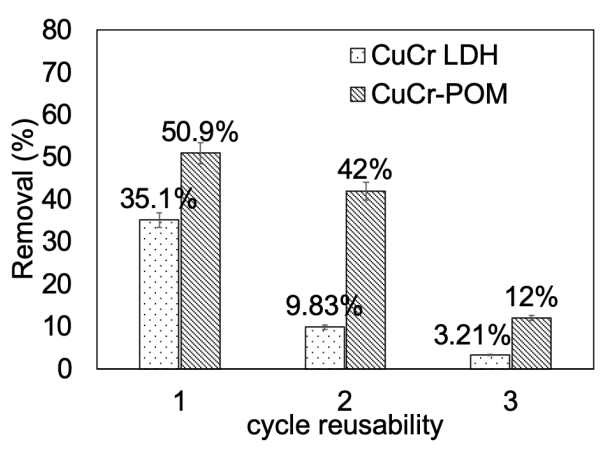

Figure 8. Reusability of Adsorbents

capacity of $\mathrm{CuCr}-\left[\alpha-\mathrm{SiW}_{12} \mathrm{O}_{40}\right]$ showed in slightly high as compared other materials assumed that $\mathrm{CuCr}-\left[\alpha-\mathrm{SiW}_{12} \mathrm{O}_{40}\right]$ is effective sorbent to remove malachite green in the aqueous phase. The increasing adsorption capacity of malachite green on $\mathrm{CuCr}-\left[\alpha-\mathrm{SiW}_{12} \mathrm{O}_{40}\right]$ is equal with increasing of interlayer space after intercalation, thus the adsorption process probably occurs mainly on the interlayer of $\mathrm{CuCr}-\left[\alpha-\mathrm{SiW}_{12} \mathrm{O}_{40}\right]$ than the surface of the adsorbent (Siregar et al., 2021).

The thermodynamic data as shown in Table 5 was also calculated from data in Figure 7. The thermodynamic parameter results were described for a higher concentration of MG, which was conducted at various temperatures. The $\Delta \mathrm{G}$ of adsorption has a negative value means adsorption of $\mathrm{MG}$ on $\mathrm{CuCr}$ and $\mathrm{CuCr}-\left[\alpha-\mathrm{SiW}_{12} \mathrm{O}_{40}\right]$ spontaneously occurred in a batch system. The $\Delta \mathrm{H}$ value is less than $40 \mathrm{~kJ} / \mathrm{mol}$ and confirms the adsorption process was endothermic (Taher et al., 2017). The value of $\Delta \mathrm{S}$ is positive for both $\mathrm{CuCr}$ and $\mathrm{CuCr}-\left[\alpha-\mathrm{SiW}_{12} \mathrm{O}_{40}\right]$ for $\mathrm{MG}$ adsorption process. Thus, this finding indicated that the increased degree of freedom of interaction between solid and solution from adsorbate and adsorbent molecules (Jaśkaniec et al., 2018; Qu et al., 2019).

LDHs are unstable materials toward acid thus the ultrasonic system was applied for a reusability test of $\mathrm{CuCr}-[\alpha-$ $\left.\mathrm{SiW}_{12} \mathrm{O}_{40}\right]$ to desorb malachite green on the adsorbent. Figure 8 showed that the adsorption capacity of $\mathrm{CuCr} \mathrm{LDH}$ largely 
Table 3. Isotherm Model Parameters of MG Adsorption Process on $\mathrm{CuCr}$ and $\mathrm{CuCr}-\left[\alpha-\mathrm{SiW}_{12} \mathrm{O}_{40}\right]$

\begin{tabular}{ccccccc}
\hline \multirow{2}{*}{$\mathrm{LDH}$} & Adsorption & Adsorption & \multicolumn{4}{c}{$\mathrm{T}(\mathrm{K})$} \\
& Isotherm & Constant & 303 & 313 & 318 & 323 \\
\hline $\mathrm{CuCr}$ & Langmuir & $\mathrm{q}_{\max }$ & 6.016 & 22.008 & 23.198 & 27.585 \\
& & $\mathrm{~kL}$ & 0.098 & 0.05 & 0.176 & 0.771 \\
& & $\mathrm{R}^{2}$ & 0.989 & 0.973 & 0.985 & 0.994 \\
& \multirow{2}{*}{ Freundlich } & $\mathrm{n}$ & 6.518 & 1.963 & 3.273 & 2.826 \\
& & $\mathrm{kF}$ & 2.725 & 2.227 & 6.555 & 6.991 \\
& & $\mathrm{R}^{2}$ & 0.785 & 0.9 & 0.964 & 0.868 \\
$\mathrm{CuCr}-\left[\alpha-\mathrm{SiW}_{12} \mathrm{O}_{40}\right]$ & Langmuir & $\mathrm{q}_{\text {max }}$ & 12.127 & 35.372 & 46.035 & 55.322 \\
& & $\mathrm{~kL}$ & 0.094 & 0.233 & 0.297 & 0.564 \\
& \multirow{2}{*}{ Freundlich } & $\mathrm{R}$ & 0.929 & 0.998 & 0.993 & 0.998 \\
& & $\mathrm{n}$ & 1.972 & 3.178 & 3.479 & 4.048 \\
& & $\mathrm{kF}$ & 1.301 & 6.586 & 17.676 & 10.664 \\
& & $\mathrm{R}^{2}$ & 0.755 & 0.855 & 0.861 & 0.645 \\
\hline
\end{tabular}

Table 4. Comparison of Malachite Green Adsorption by Several Adsorbents

\begin{tabular}{ccc}
\hline Adsorbents & $\mathrm{q}_{\max }$ & Ref. \\
\hline $\mathrm{NiAl}$ LDH & 27.32 & (Lesbani et al., 2020c) \\
$\mathrm{CuAl} \mathrm{LDH}$ & 55.22 & (Palapa et al., 2020a) \\
CuAl-LDH/BC & 470.96 & (Palapa et al., 2020c) \\
ZnAl LDH & 11.1 & (Palapa et al., 2018) \\
Apricot-AC & 17.6 & (Abbas, 2020) \\
Leucaena leucocephala & 2.389 & (Lee et al., 2018) \\
NiFe-LDH/calcined & 73.68 & (Elmoubarki et al., 2017) \\
MW-Carbon nanotubes & 11.95 & (Rajabi et al., 2016) \\
CuCr LDH & 27.585 & This work \\
CuCr- $\left[\alpha-\mathrm{SiW}_{12} \mathrm{O}_{40}\right]$ & 55.322 & This work \\
\hline
\end{tabular}

Table 5. Thermodynamic Parameter of MG Adsorption on $\mathrm{CuCr}$ and $\mathrm{CuCr}-\left[\alpha-\mathrm{SiW}_{12} \mathrm{O}_{40}\right]$

\begin{tabular}{cccccc}
\hline Adsorbents & $\mathrm{T}(\mathrm{K})$ & $\mathrm{Qe}(\mathrm{mg} / \mathrm{g})$ & $\Delta \mathrm{G}(\mathrm{kJ} / \mathrm{mol})$ & $\Delta \mathrm{S}(\mathrm{J} / \mathrm{mol} \mathrm{K})$ & $\Delta \mathrm{H}(\mathrm{kJ} / \mathrm{mol})$ \\
\hline $\mathrm{CuCr} \mathrm{LDH}$ & 303 & 27.357 & -1.455 & 35.792 & 12.3 \\
& 313 & 28.516 & -1.097 & & \\
& 318 & 31.807 & -0.918 & & \\
$\mathrm{CuCr}-\left[\alpha-\mathrm{SiW}_{12} \mathrm{O}_{40}\right]$ & 323 & 32.434 & -0.739 & & \\
& 303 & 41.421 & -0.552 & 39.7457 & 11.491 \\
& 313 & 44.678 & -0.9494 & & \\
& 318 & 45.382 & -1.1482 & & \\
& 323 & 46.606 & -1.3469 & & \\
\hline
\end{tabular}

decreased after two cycles adsorption process while $\mathrm{CuCr}-[\alpha-$ $\left.\mathrm{SiW}_{12} \mathrm{O}_{40}\right]$ relatively stable. The three cycles adsorption process of malachite green showed that adsorption capacity for both adsorbents was decreased. On the other hand, the adsorption capacity of $\mathrm{CuCr}-\left[\alpha-\mathrm{SiW}_{12} \mathrm{O}_{40}\right]$ has almost slightly larger than pristine LDHs. Thus, the intercalation process was increased the structural stability of LDHs.

\section{CONCLUSIONS}

The intercalated $\mathrm{CuCr} \mathrm{LDH}$ using polyoxometalate Keggin anion to form $\mathrm{CuCr}-\left[\alpha-\mathrm{SiW}_{12} \mathrm{O}_{40}\right]$ was successfully prepared and analyzed by XRD, FTIR and surface area analysis. The $\mathrm{CuCr}-\left[\alpha-\mathrm{SiW}_{12} \mathrm{O}_{40}\right]$ was applied as an adsorbent of MG. The effect of adsorption time showed the optimum uptake after 100 minutes. Material $\mathrm{CuCr}-\left[\alpha-\mathrm{SiW}_{12} \mathrm{O}_{40}\right]$ has a higher adsorption capacity than pristine LDHs due to high surface area 
properties. The kinetic parameters showed that the adsorption process follows PS-O kinetic model. Langmuir isotherm was appropriate than Freundlich isotherm models for both adsorbents. Material $\mathrm{CuCr}-\left[\alpha-\mathrm{SiW}_{12} \mathrm{O}_{40}\right]$ has higher $\mathrm{Q}_{\max }(55.322$ $\mathrm{mg} / \mathrm{g}$ at $323 \mathrm{~K})$ than $\mathrm{CuCr}$ LDHs $(27.585 \mathrm{mg} / \mathrm{g}$ at $323 \mathrm{~K})$. Thermodynamic parameter results showed the negativity of $\Delta \mathrm{G}$ with increasing temperature indicated that the adsorption favorable in high temperature. Enthalpy of adsorption showed the value is less than $40 \mathrm{~kJ} / \mathrm{mol}$ and the adsorption process was endothermic. The positive value of $\Delta \mathrm{S}$ denotes the concentration of adsorbate has high interaction with adsorbent and affected the entropy to be increased. Structural stability of $\mathrm{CuCr}$ LDHs was slightly increased after the intercalation process.

\section{ACKNOWLEDGEMENT}

We thank Ministry of National Education and Culture, Republik Indonesia for financial support through HIBAH DISERTASI DOKTOR 2020-2021 from Directorate General Higher Edication (DIKTI) Republic Indonesia with primary contract number : 054/E4.1/AK.04.PT/2021 and derivative contract number : 0163.02/UN9/SB3.LP2M.PT/2021. We also gratefully acknowledge to Research Center of Inorganic Materials and Complexes FMIPA Universitas Sriwijaya for instrumental analysis.

\section{REFERENCES}

Abbas, M. (2020). Experimental investigation of activated carbon prepared from apricot stones material (ASM) adsorbent for removal of malachite green (MG) from aqueous solution. Adsorption Science \& Technology, 38(2); 24-45

Abdelkader, N. B.-H., A. Bentouami, Z. Derriche, N. Bettahar, and L.-C. De Menorval (2011). Synthesis and characterization of $\mathrm{Mg}-\mathrm{Fe}$ layer double hydroxides and its application on adsorption of Orange $\mathrm{G}$ from aqueous solution. Chemical Engineering Journal, 169(3); 231-238

Bi, B., L. Xu, B. Xu, and X. Liu (2011). Heteropoly blueintercalated layered double hydroxides for cationic dye removal from aqueous media. Applied Clay Science, 54(4); 242-247

Bulut, E., M. Özacar, and İ. A. Şengil (2008). Adsorption of malachite green onto bentonite: equilibrium and kinetic studies and process design. Microporous and Mesoporous Materials, 115(3); 234-246

Carriazo, D., S. Lima, C. Martín, M. Pillinger, A. Valente, and V. Rives (2007). Metatungstate and tungstoniobatecontaining LDHs: Preparation, characterisation and activity in epoxidation of cyclooctene. Journal of Physics and Chemistry of Solids, 68(10); 1872-1880

Dahri, M. K., M. R. R. Kooh, and L. B. Lim (2014). Water remediation using low cost adsorbent walnut shell for removal of malachite green: equilibrium, kinetics, thermodynamic and regeneration studies. Journal of Environmental Chemical Engineering, 2(3); 1434-1444
Dai, L., W. Zhu, L. He, F. Tan, N. Zhu, Q. Zhou, M. He, and G. Hu (2018). Calcium-rich biochar from crab shell: An unexpected super adsorbent for dye removal. Bioresource Technology, 267; 510-516

Daniel, S. and S. Thomas (2020). Layered double hydroxides: fundamentals to applications Elsevier, 1-76

Das, S., S. K. Dash, and K. Parida (2018). Kinetics, isotherm, and thermodynamic study for ultrafast adsorption of azo dye by an efficient sorbent: ternary $\mathrm{Mg} /(\mathrm{Al}+\mathrm{Fe})$ layered double hydroxides. ACS Omega, 3(3); 2532-2545

Doğan, M. and M. Alkan (2003). Adsorption kinetics of methyl violet onto perlite. Chemosphere, 50(4); 517-528

Doungmo, G., T. Kamgaing, R. C. T. Temgoua, E. Ymele, F. M. M. Tchieno, and I. K. Tonlé (2016). Intercalation of oxalate ions in the interlayer space of a layered double hydroxide for nickel ions adsorption. International Journal of Basic and Applied Sciences, 5(2); 144

Elmoubarki, R., F. Z. Mahjoubi, A. Elhalil, H. Tounsadi, M. Abdennouri, M. Sadiq, S. Qourzal, A. Zouhri, and N. Barka (2017). Ni/Fe and $\mathrm{Mg} / \mathrm{Fe}$ layered double hydroxides and their calcined derivatives: preparation, characterization and application on textile dyes removal. Journal of Materials Research and Technology, 6(3); 271-283

Gholami, P., A. Khataee, R. D. C. Soltani, L. Dinpazhoh, and A. Bhatnagar (2020). Photocatalytic degradation of gemifloxacin antibiotic using Zn-Co-LDH@biochar nanocomposite. Journal of Hazardous Materials, 382; 121070

Harizi, I., D. Chebli, A. Bouguettoucha, S. Rohani, and A. Amrane (2019). A new $\mathrm{Mg}-\mathrm{Al}-\mathrm{Cu}-\mathrm{Fe}-\mathrm{LDH}$ composite to enhance the adsorption of acid red 66 dye: Characterization, kinetics and isotherm analysis. Arabian Journal for Science and Engineering, 44(6); 5245-5261

Jarrah, N., N. D. Mu'azu, M. Zubair, and M. Al-Harthi (2020). Enhanced adsorptive performance of $\mathrm{Cr}$ (VI) onto layered double hydroxide-bentonite composite: Isotherm, kinetic and thermodynamic studies. Separation Science and Technology, 55(11); 1897-1909

Jaśkaniec, S., C. Hobbs, A. Seral-Ascaso, J. Coelho, M. P. Browne, D. Tyndall, T. Sasaki, and V. Nicolosi (2018). Lowtemperature synthesis and investigation into the formation mechanism of high quality Ni-Fe layered double hydroxides hexagonal platelets. Scientific Reports, 8(1); 1-8

Lee, Y. C., M. H. M. Amini, N. S. Sulaiman, M. Mazlan, and J. G. Boon (2018). Batch adsorption and isothermic studies of malachite green dye adsorption using Leucaena leucocephala biomass as potential adsorbent in water treatment. Songklanakarin Journal of Science and Technology, 40(3); 563-569

Legagneux, N., E. Jeanneau, J.-M. Basset, and F. Lefebvre (2009). Trialkyl tin salts of polyoxometalates: synthesis and characterization of $\left[\alpha-\mathrm{SiW}_{12} \mathrm{O}_{40}\right]\left[\left(\mathrm{CH}_{3}\right) 3 \mathrm{Sn}(\mathrm{DMSO})\right.$ 2]4·2DMSO. Journal of Molecular Structure, 921(3); 300306

Lesbani, A., F. Asri, N. Palapa, T. Taher, and A. Rachmat (2020a). Efficient removal of methylene blue by adsorp- 
tion using composite based $\mathrm{Ca} / \mathrm{Al}$ layered double hydroxidebiochar. Global NEST J, 22(2); 250-257

Lesbani, A., H. Hensen, T. Taher, N. Hidayati, R. Mohadi, and R. Andreas (2018). Intercalation of $\mathrm{Zn} / \mathrm{Al}$ layered double hydroxides with keggin ion as adsorbent of Cadmium (II). AIP Conference Proceeding, 2026(1); 020011

Lesbani, A., A. Marpaung, M. Verawaty, H. R. Amalia, and R. Mohadi (2015). Catalytic desulfurization of benzothiophene using Keggin type polyoxometalates as catalyst. The Journal of Pure and Applied Chemistry Research, 4(1); 5-11

Lesbani, A., T. Taher, N. Palapa, R. Mohadi, A. Yuliana, et al. (2020b). Methyl orange dye removal using $\mathrm{Ni} / \mathrm{Fe}-\mathrm{NO}_{3}$ and $\mathrm{Ni} / \mathrm{Fe}-\left[\alpha-\mathrm{SiW}_{12} \mathrm{O}_{40}\right]$ layered double hydroxides. IOP Conference Series: Materials Science and Engineering, 902(1); 012042

Lesbani, A., T. Taher, N. R. Palapa, R. Mohadi, A. Rachmat, et al. (2020c). Preparation and utilization of Keggin-type polyoxometalate intercalated Ni-Fe layered double hydroxides for enhanced adsorptive removal of cationic dye. $S N$ Applied Sciences, 2(3); 1-4

Liao, X.-J. and G.-S. Chen (2016). A hybrid hydrogel based on clay nanoplatelets and host-guest inclusion complexes. Chinese Chemical Letters, 27(4); 583-587

Long, D.-L., R. Tsunashima, and L. Cronin (2010). Polyoxometalates: building blocks for functional nanoscale systems. Angewandte Chemie International Edition, 49(10); 1736-1758

Ma, S., J. Wang, L. Du, Y. Sun, Q. Gu, G. Sun, and X. Yang (2013). A new method for fast intercalation of bulk crown ether guest into LDH. Journal of Colloid and Interface Science, 393(1); 29-35

Mall, I. D., V. C. Srivastava, N. K. Agarwal, and I. M. Mishra (2005). Adsorptive removal of malachite green dye from aqueous solution by bagasse fly ash and activated carbonkinetic study and equilibrium isotherm analyses. Colloids and Surfaces A: Physicochemical and Engineering Aspects, 264(3); 17-28

Mohadi, R., N. R. Palapa, and A. Lesbani (2021). Preparation of $\mathrm{Ca} / \mathrm{Al}$-Layered Double Hydroxides/Biochar Composite with High Adsorption Capacity and Selectivity toward Cationic Dyes in Aqueous. Bulletin of Chemical Reaction Engineering \& Catalysis, 16(2); 244-252

Naseeruteen, F., N. S. A. Hamid, F. B. M. Suah, W. S. W. Ngah, and F. S. Mehamod (2018). Adsorption of malachite green from aqueous solution by using novel chitosan ionic liquid beads. International Journal of Biological Macromolecules, 107; 1270-1277

Nazir, M. A., N. A. Khan, C. Cheng, S. S. A. Shah, T. Najam, M. Arshad, A. Sharif, S. Akhtar, and A. ur Rehman (2020). Surface induced growth of ZIF-67 at Co-layered double hydroxide: Removal of methylene blue and methyl orange from water. Applied Clay Science, 190; 105564

Nijs, H., M. De Bock, and E. Vansant (1999). Comparative study of the synthesis and properties of polyoxometalate pillared layered double hydroxides (POM-LDHs). Journal of Porous Materials, 6(2); 101-110
Obike, A., J. Igwe, C. Emeruwa, and K. Uwakwe (2018). Equilibrium and kinetic studies of $\mathrm{Cu}$ (II), $\mathrm{Cd}$ (II), $\mathrm{Pb}$ (II) and $\mathrm{Fe}$ (II) adsorption from aqueous solution using cocoa (Theobroma cacao) pod husk. Journal of Applied Sciences and Environmental Management, 22(2); 182-190

Oktriyanti, M., N. R. Palapa, R. Mohadi, and A. Lesbani (2020). Effective removal of iron (II) from aqueous solution by adsorption using $\mathrm{Zn} / \mathrm{Cr}$ layered double hydroxides intercalated with Keggin ion. Journal of Ecological Engineering, $21(5) ; 63-71$

Oliveira, J. A., F. A. Cunha, and L. A. Ruotolo (2019). Synthesis of zeolite from sugarcane bagasse fly ash and its application as a low-cost adsorbent to remove heavy metals. Journal of Cleaner Production, 229; 956-963

Ouassif, H., E. M. Moujahid, R. Lahkale, R. Sadik, F. Z. Bouragba, M. Diouri, et al. (2020). Zinc-Aluminum layered double hydroxide: High efficient removal by adsorption of tartrazine dye from aqueous solution. Surfaces and Interfaces, 18; 100401

Palapa, N. R., N. Juleanti, N. Normah, T. Taher, and A. Lesbani (2020a). Unique adsorption properties of malachite green on interlayer space of $\mathrm{Cu}-\mathrm{Al}$ and $\mathrm{Cu}-\mathrm{Al}-\mathrm{SiW}_{12} \mathrm{O}_{40}$ layered double hydroxides. Bulletin of Chemical Reaction Engineering \& Catalysis, 15(3); 653-661

Palapa, N. R., R. Mohadi, A. Rachmat, et al. (2020b). Adsorption study of malachite green removal from aqueous solution using $\mathrm{Cu} / \mathrm{M}^{3+}\left(\mathrm{M}^{3+}=\mathrm{Al}, \mathrm{Cr}\right)$ layered double hydroxide. Mediterranean Journal of Chemistry, 10(1); 33-45

Palapa, N. R., T. Taher, R. Mohadi, M. Said, and A. Lesbani (2018). Synthesis of $\mathrm{Ni} / \mathrm{Al}$ layered double hydroxides (LDHs) for adsorption of malachite green and direct yellow dyes from solutions: Kinetic and thermodynamic. AIP Conference Proceedings, 2026(1); 020033

Palapa, N. R., T. Taher, B. R. Rahayu, R. Mohadi, A. Rachmat, and A. Lesbani (2020c). CuAl LDH/Rice husk biochar composite for enhanced adsorptive removal of cationic dye from aqueous solution. Bulletin of Chemical Reaction Engineering $\mathcal{E}^{\circ}$ Catalysis, 15(2); 525-537

Parida, K. and L. Mohapatra (2012). Carbonate intercalated $\mathrm{Zn} / \mathrm{Fe}$ layered double hydroxide: a novel photocatalyst for the enhanced photo degradation of azo dyes. Chemical Engineering Journal, 179; 131-139

Qu, W., T. Yuan, G. Yin, S. Xu, Q. Zhang, and H. Su (2019). Effect of properties of activated carbon on malachite green adsorption. Fuel, 249; 45-53

Rajabi, M., B. Mirza, K. Mahanpoor, M. Mirjalili, F. Najafi, O. Moradi, H. Sadegh, R. Shahryari-Ghoshekandi, M. Asif, I. Tyagi, et al. (2016). Adsorption of malachite green from aqueous solution by carboxylate group functionalized multiwalled carbon nanotubes: determination of equilibrium and kinetics parameters. Journal of Industrial and Engineering Chemistry, 34; 130-138

Shan, R.-r., L.-g. Yan, Y.-m. Yang, K. Yang, S.-j. Yu, H.-q. Yu, B.-c. Zhu, and B. Du (2015). Highly efficient removal of three red dyes by adsorption onto $\mathrm{Mg}-\mathrm{Al}$-layered double 
hydroxide. Journal of Industrial and Engineering Chemistry, 21; 561-568

Silaen, P. N. R. J. N. M. R. . L. A., L. (2020). Efficient Adsorption of Cadmium (II) on $\mathrm{Zn} / \mathrm{M}^{3+}\left(\mathrm{M}^{3+}=\mathrm{Al}, \mathrm{Cr}\right) . A R P N$ Journal, 15(18); 1967-1975

Siregar, P. M. S. B. N., N. R. Palapa, A. Wijaya, E. S. Fitri, and A. Lesbani (2021). Structural stability of Ni/Al layered double hydroxide supported on graphite and biochar toward adsorption of congo red. Science and Technology Indonesia, 6(2); 85-95

Srinivasan, S. and S. K. Sadasivam (2018). Exploring docking and aerobic-microaerophilic biodegradation of textile azo dye by bacterial systems. Journal of water process engineering, 22; 180-191

Starukh, H. and S. Levytska (2019). The simultaneous anionic and cationic dyes removal with $\mathrm{ZnAl}$ layered double hydroxides. Applied Clay Science, 180; 105183

Sun, X., J. Dong, Z. Li, H. Liu, X. Jing, Y. Chi, and C. Hu (2019). Mono-transition-metal-substituted polyoxometalate intercalated layered double hydroxides for the catalytic decontamination of sulfur mustard simulant. Dalton Transactions, 48(16); 5285-5291

Taher, T., M. M. Christina, M. Said, N. Hidayati, F. Ferlinahayati, and A. Lesbani (2019). Removal of iron (II) using intercalated $\mathrm{Ca} / \mathrm{Al}$ layered double hydroxides with $[\alpha-$ $\left.\mathrm{SiW}_{12} \mathrm{O}_{40}\right]^{4-}$. Bulletin of Chemical Reaction Engineering $\mathcal{E}^{\circ}$ Catalysis, 14(2); 260-267

Taher, T., R. Mohadi, D. Rohendi, and A. Lesbani (2017). Kinetic and thermodynamic adsorption studies of congo red on bentonite. AIP Conference Proceedings, 1823(1); 020028 $\mathrm{Xu}$, M., B. Bi, B. Xu, Z. Sun, and L. Xu (2018a). Polyoxometalate-intercalated ZnAlFe-layered double hydroxides for adsorbing removal and photocatalytic degradation of cationic dye. Applied Clay Science, 157; 86-91

Xu, Y., Z. Li, K. Su, T. Fan, and L. Cao (2018b). Musselinspired modification of PPS membrane to separate and remove the dyes from the wastewater. Chemical Engineering Journal, 341; 371-382

Yang, R., S.-X. Liu, Q. Tang, S.-J. Li, and D.-D. Liang (2012). Synthesis, structure, and catalytic activity of Keggin-type polyoxometalate coordinated $\mathrm{Cu}(\mathrm{I}):\left\{\left[\mathrm{Cu}(\mathrm{py})_{2}\right]^{4}\left[\mathrm{SiW}_{12} \mathrm{O}_{40}\right]\right\}$, via hydrothermal decarboxylation. Journal of Coordination Chemistry, 65(5); 891897

Yun, S. K. and T. J. Pinnavaia (1996). Layered double hydroxides intercalated by polyoxometalate anions with Keggin $\left(\alpha-\mathrm{H}_{2} \mathrm{~W}_{12} \mathrm{O}_{40}{ }^{6-}\right)$, Dawson $\left(\alpha-\mathrm{P}_{2} \mathrm{~W}_{18} \mathrm{O}_{62}{ }^{6-}\right)$, and Finke $\left(\mathrm{Co}_{4}\left(\mathrm{H}_{2} \mathrm{O}\right)_{2}\left(\mathrm{PW}_{9} \mathrm{O}_{34}\right)_{2}{ }^{10-}\right)$ structures. Inorganic chemistry, 35(23); 6853-6860

Zhu, Y., J. Rong, T. Zhang, J. Xu, Y. Dai, and F. Qiu (2017). Facile and controlled fabrication of $\mathrm{Cu}-\mathrm{Al}$ layered double hydroxide nanosheets/laccase hybrid films: a route to efficient biocatalytic removal of congo red from aqueous solutions. ACS Applied Nano Materials, 1(1); 284-292

Zubair, M., M. Daud, G. McKay, F. Shehzad, and M. A. AlHarthi (2017). Recent progress in layered double hydroxides (LDH)-containing hybrids as adsorbents for water remediation. Applied Clay Science, 143; 279-292 